\title{
Azoles: Introduction, Current and Future Scope
}

Vinod Kumar $^{1^{*}}$, Sunil Kumar ${ }^{2}$ and Girish Kumar Gupta ${ }^{3}$

${ }^{1}$ Department of Chemistry, Maharishi Markandeshwar University, Mullana, Ambala, Haryana, India

${ }^{2}$ Department of Chemistry, Govt Girls P.G. College, Hisar, Haryana, India

${ }^{3}$ Department of Pharmaceutical Chemistry, Maharishi Markandeshwar University, Mullana, Ambala, India

${ }^{*}$ Corresponding author: Kumar V, Department of Chemistry, Maharishi Markandeshwar University, Mullana, Ambala, Haryana, India, Tel: 08059930169; E-mail: vinodbatan@gmail.com

Received Date: June 13, 2016, Accepted Date: June 22, 2016, Published Date: June 24, 2016

Copyright: (c) 2016 Kumar V, et al. This is an open-access article distributed under the terms of the Creative Commons Attribution License, which permits unrestricted use, distribution, and reproduction in any medium, provided the original author and source are credited.

Citation: Kumar V, Kumar S, Gupta GK (2016) Azoles: Introduction, Current and Future Scope. Bioenergetics 5: 224.

\section{Introduction}

Azoles are five-membered nitrogen containing heterocycles and some of them are widely distributed in nature. Owing to diverse biological properties they have gained much more attention in different fields of science. Most of the drugs are either originally natural products or their biomimetic compounds and a large number bearing different kinds of azoles. Viewing the immense significance, we pursued the research study on some important Azole derivatives, particularly, Pyrazole I, Imidazole II, Triazole III, Isoxazole IV, Oxadiazole V and thiazole VI compounds [1-10]. (Figure 1).<smiles></smiles>

Figure 1: Some important Azole derivatives (I-VI).

Globally, though a large number of compounds belonging to azole family have been designed and synthesized, we have also contributed significantly to add some new highlights in this field. Our main focus centers on the establishment of the structures of a wide variety of novel azoles on the basis of their NMR $\left({ }^{1} \mathrm{H},{ }^{13} \mathrm{C}\right.$ and $\left.{ }^{19} \mathrm{~F}\right)$ spectral characteristics besides to explore their biological potential. Research interests focusing on the structural reinvestigations, greener approaches, synthetic, and mechanistic aspects of azoles of medicinal interests also remain the parts of the core areas of research. In recent past, our group has synthesized some novel anti-cancer, DNA photocleaving agents, anti-inflammatory and antimicrobial azole derivatives. In future, the design and synthesis of the hybrids of these heterocycles may generate a lot of opportunities in the field of medicinal chemistry [11-22].

\section{References}

1. Aggarwal R, Pundeer R, Kumar V, Chaudhari V, Singh SP, et al. (2004) A Facile Synthesis of Thiazole-2(3H)-thiones Through [Hydroxy (tosyloxy) iodo] benzene Synth. Commun 34: 2659-2664.

2. Sanz D, Claramunt RM, Singh SP, Kumar V, Aggarwal R, et al. (2005) Structure of the products of condensation of hydroxylamine with trifluoromethyl-beta-diketones: assignments of the diastereotopic protons of the 4-methylene group in 5-hydroxy-5-trifluoromethyl-delta2isoxazolines. Magn Reson Chem 43: 1040-1043.

3. Kumar V, Aggarwal R, Tyagi P, Singh SP (2005) Synthesis and antibacterial activity of some new 1-heteroaryl-5-amino-4-phenyl-3trifluoromethylpyrazoles. Eur J Med Chem 40: 922-927.

4. Aggarwal R, Kumar V, Tyagi P, Singh SP (2006) Synthesis and antibacterial activity of some new 1-heteroaryl-5-amino-3H/methyl-4phenylpyrazoles. Bioorg Med Chem 14: 1785-1791.

5. Aggarwal R, Kumar R, Kumar V (2007) A facile and rapid one-pot synthesis of , 4-diaryl-2-mercaptoimidazoles under solvent-free conditions. J Sulfur Chem 28: 617-623.

6. Gupta GK, Kumar V, Kumar V (2011) Pyrazoles as potential anti-obesity agents. Res J Chem Environ 15: 90-103.

7. Sharma AK, Naithani R, Kumar V, Sandhu SS (2011) Iron regulation in tuberculosis research: promise and challenges. Curr Med Chem 18: 1723-1731.

8. Gupta GK, Rani N, Kumar V (2012) Microwave assisted synthesis of imidazoles-A review. Mini-Rev Org Chem 9: 270-284.

9. Kumar V, Kaur K, Gupta GK, Sharma AK (2013) Pyrazole containing natural products: synthetic preview and biological significance. Eur J Med Chem 69: 735-753.

10. Saini RP, Kumar V, Gupta AK, Gupta GK (2014) Synthesis, characterization and antibacterial activity of a novel heterocyclic Schiff's base and its metal complexes of first transition series. Med Chem Res 23: 690-698.

11. Kaur K, Kumar V, Sharma AK, Gupta GK (2014) Isoxazoline containing natural products as anticancer agents: a review. Eur J Med Chem 77: 121-133.

12. Kumar V, Kaur K, Karelia DN, Beniwal V, Gupta GK, et al. (2014) Synthesis and biological evaluation of some 2-(,5-dimethyl-1H-pyrazol-1yl)-1-arylethanones: antibacterial, DNA photocleavage, and anticancer activities. Eur J Med Chem 81: 267-276.

13. Singh K, Verma V, Yadav K, Sreekanth V, Kumar D, et al. (2014) Design, regioselective synthesis and cytotoxic evaluation of 2-aminoimidazolequinoline hybrids against cancer and primary endothelial cells. Eur J Med Chem 87: 150-158.

14. Kumar M, Kumar V, Gupta GK (2014) Synthesis, antibacterial evaluation, and SAR study of some novel 3-aryl/heteroaryl-9-methyl-1,2,4-triazolo-[, 3-a]-quinoline derivatives. Med Chem Res 24: 1857-1868.

15. Sharma A, Kumar V, Khare R, Gupta GK, Beniwal V (2014) Synthesis, docking study, and DNA photocleavage activity of some pyrimidinyl 
Citation: Kumar V, Kumar S, Gupta GK (2016) Azoles: Introduction, Current and Future Scope. Bioenergetics 5: 224. doi: 10.4172/2167-7662.1000224

Page 2 of 2

hydrazones and 3-(quinolin-3-yl)-,7-dimethyl-,,4-triazolo[,3a]pyrimidine derivatives. Med Chem Res 24: 1830-1841.

16. Kumar M, Kumar V, Beniwal V (2015) Synthesis of some pyrazolylaldehyde $\mathrm{N}$-isonicotinoyl hydrazones and 5-disubstituted,4oxadiazoles as DNA photocleaving agents. Med Chem Res 24: 2862-2870.

17. Kumar V, Kaur K (2015) Fluorinated isoxazolines and isoxazoles: A synthetic perspective. J Fluorine Chem 180: 55-97.

18. Kaur K, Kumar V, Gupta GK (2015) Trifluoromethylpyrazoles as antiinflammatory and antibacterial agents: A review. J Fluorine Chem 178 306-326.
19. Kaur K, Kumar V, Beniwal V, Kumar V, Aneja KR, et al. (2015) Solventfree synthesis of novel (E)-2-(,5-dimethyl-4-(aryldiazenyl)-1H-pyrazol-1yl)-4-arylthiazoles: Determination of their biological activity. Med Chem Res 24: 3863- 3874.

20. Kumar H, Kumar V (2016) Copper(I) Catalyzed Azide-Alkyne Click Reaction: Synthesis and Metal-Ion Binding Studies of Some 3-Triazole Derivatives. Asian Journal of Chemistry 28: 613-616.

21. Gupta GK, Kumar V (2016) Chemical Drug Design, De Gruyter.

22. Kumar S, Kumar V, Singh SP (2016) Pericyclic Reactions: A Mechanistic and Problem Solving Approach, (1st edn.), Academic Press Inc. 